\title{
Comparative study of risk management practices of Islamic versus conventional banks in Pakistan
}

\author{
Faizan Yasin \\ FUIRC, Department of Business \& Economics. \\ Foundation University, 44000, Islamabad, Pakistan
}

\section{Introduction}

The conventional banking system is based on interest cost mechanism. On the other hand, the interest cost is prohibited in the Islamic financial system. The history of Islamic and conventional banking system goes back to hundreds and thousands of years. Risk refers to the uncertainty and inconsistency in returns of an organization with particular assets (Gitman, 2008). On the other hand, risk can also be defined as an amalgamation of the probability of the occurrence of an event and its consequence (Hassan, 2009). The risk management strategies of organizations vary from business to business and industry to industry. In this particular study, the techniques of risk management have been evaluated in the conventional and Islamic banking systems. Specifically, this particular research has been focused to evaluate that how conventional and Islamic banks manage equity investment, market, operational risk, rate of return and liquidity. In this regard, the research is going to evaluate that whether there is an association in the risk management strategies of conventional and Islamic banks. In this regard, the research also provides an appropriate framework to determine that whether banks are able to manage their risks appropriately. In perspective of Pakistan, existing studies in this regard are rare. In this regard, this particular study is going to fill the void in literature by exploring the risk management strategies of conventional and Islamic banks. The IFSB has recently finalized standards on capital adequacy and risk management, and has made progress in developing standards on corporate governance. Once developed and accepted, these international standards will assist supervisors in pursuing soundness, stability, and integrity in the world of Islamic finance

The core purpose of this particular study is to evaluate the degree to which conventional and Islamic banks have adopted risk management strategies while dealing with several types of risks. In this regard, the study is also going to find that whether there are significant differences in the risk management strategies of conventional and Islamic banks.

\subsection{Overview of Islamic Banking}

\section{Literature Review}

Hasan and Dridi (2010) note that the doubts regarding the proper functioning of conventional banking after the global financial and economic crises of 2007 and 2008 has increased significantly. Coupled with that, the better performance of Islamic Banking during the same time period has been noted by a number of observers. Apart from this, Beck, Kunt and Merrouche (2013) say that both the academicians and policy makers have pointed out the benefits of Sharia compliant financial products especially in response to the adverse impacts that the industry has suffered because of the conventional banking.

That said, and the financial and economic recession having significantly subsided, the total investment in Islamic Assets according to Financial Times (2011) is still 900 billion dollars, which even though has doubled from 2006 to 2011 , is still only $1.5 \%$ of the total banking assets in the world.

According to Nawi et al (2013), Islamic Banking was originally developed to cater to the needs of a significant market segment that is, Muslims customers. Apart from just the Muslims however, non Muslim consumers and non muslim business capitalists are also found to be adopting the services and the ideas of Islamic Banking. The question then that the author raised was what the factors that have affected the growth and adoption of Islamic Banking are, with special focus on Malaysia. According to the findings of the research, the compliance with the Shariah, the quality and attractiveness off the offer and the preferences towards potentials of Islamic banking were the factors that positively affected the adoption of Islamic Finance and Banking by customers.

An important question in regards to Islamic Banking is whether or not it has asset quality, stability and efficiency or not. For this Beck, Kunt and Merrouche (2013) emphasize that it is important to compare the two business models and their risks and returns. Focusing on this issue for example, Kuran (2004) says that even though it has been argued that Islamic Banking is more efficient and more stable than conventional banking, the reality is that the two are only different in form but in their substance and offerings, the two are the same. This 
means inherently that Islamic banking does not have any superiority over conventional banking. Chong and Liu (2009) however have a different opinion. According to Chong and Liu (2009), Islamic Finance is very different from conventional banking. The reason for this is that Sharia compliant or Islamic banking does not allow for the paying and charging of riba that is, interest payments. Furthermore, Islamic financing prohibits the use of money as a commodity as it does not have intrinsic value and also prohibits the indulgence and investment of illegal and illicit activities. According to Beck, Kunt and Merrouche (2013), there is no clear indication in the theoretical frameworks as to whether Islamic Banking is actually cost effective and stable or not and thus it is vital to analyze why investors would select Islamic Banking as a choice of Investment.

A research conducted on the perception of clients towards Islamic Banks in Bangladesh by Rashid, Hassan and Ahmed (2010) revealed that customers are satisfied with the convenience, and religious compliance of the Islamic banking institutions in their country. However the reputation of the bank and the level of service delivery were noted to be important variables that impact the decision of the customers to choose a particular bank.

Focusing on the needs and wants of the corporate customers, a study by Ahmad and Harun (2002) finds that the cost of financing is the most important consideration for corporate customers. This is true with due regards to the issue of religious differences. According to Ahmad and Harun (2002), the corporate customer since are getting financial services for the organization rather than for themselves are less inclined and pressurized to have religious compliance rather the sole concern for them is to have the lowest cost of finances.

\subsection{Banking Risk Management}

Risks in banking are those that the organizations face during the implementation of the current operations. These interestingly, whatever the virtues of the Islamic Banking are not only associated with just traditional banking. Bank risks basically are the level of losses that the banks suffer because it faces the difficulty of paying its obligations. According to available literature Lee, Koh and Kang (2011), and Beck, Kunt and Merrouche (2013), shariah compliant finance is developed on the bases of profit as well as risk shares which means that there is compliance on both the asset as well as the liabilities side. Beck, Kunt and Merrouche (2013) in regards to the risk management techniques of Islamic Banking notes that the Islamic banks are less cost effective than the conventional banks however they have a better intermediation ratio. Moreover, the quality of assets as well as the capital to assets ratio is higher which suggests that Islamic banks have a more conservative risk management approach and is more averse in risk taking than is the conventional banks. One of the reasons for this is that the Islamic Finance law does not allow for speculation which is otherwise a prominent part of the conventional finance and banking. This allows the Islamic Banks to have lesser returns but also lesser risks. This forms the basis of the risk management approaches of Islamic Banking.

Beck, Kunt and Merrouche (2013) point out another extremely important element of Shariah according to which gharar that is, risk or speculation is prohibited in Islam. In this, Diamond and Rajan (2001) note that risk sharing is an important element of the risk management approach in Islamic Banking. Because the overall risk is shared, the risk attributable per person is reduced which allows not only for more stable financial relationships in Islamic Banking for example, the customer will feel more secure with the bank and vice versa and the loss in case any will not affect only one party. The impact of this risk management approach of Islamic Banking is that the risk on the balance sheet is reduced making the banking operations more stable.

Moreover, Diamond and Rajan (2001) note that Shariah compliant risk management is more equity like in which the borrowers as well as the lenders are made partners in business with the bank for providing or borrowing finances from it. In this, the inclination of shariah compliant banking is more towards equity than toward debt which automatically lowers the risk of default faced by the organization. The down side of this however is that the Islamic Banks, with their increased use of equity face higher costs at any given time than do the conventional banks which leads to a competitive disadvantage in terms of profitability for the Islamic financial institutions.

\section{Methodology}

For evaluating differences in the risk management strategies of conventional and Islamic banks, quantitative research methodology has been chosen. The quantitative research methodology has allowed the researcher to get an empirical evidence of differences in the risk management strategies of conventional and Islamic banks in Pakistan. Through this methodology, the researcher can specify the extent of differences between risk management strategies between conventional and Islamic banks of Pakistan.

In order to implement a quantitative research methodology, questionnaire survey method has been used. In this regard, questionnaires were personally distributed and administered to make this method most reliable and time saving. At the same time, some questionnaires were also sent to respondents through email and administered in an appropriate manner. The questionnaires were emailed to those banks which were not physically accessible. The targeted population of this questionnaire survey is the senior management of banks. 
The targeted population of this research is based on relationship associates, chief risk officers, credit officers, senior risk managers, branch managers and financial controllers. In this way, this particular study has analysed the practices of banks regarding risk management strategies and practices.

The questionnaire for the research was developed by researcher in English language on the basis of variables identified in the literature review. These variables were linked to the literature review. The questionnaire was adapted from a study conducted by Tafri et al. (2011). The questionnaire was developed on a close ended design having a five-point scale. The questionnaire was based on two major sections. The first section was aimed at the collection of information regarding the employees and respondents working in the conventional and Islamic banks whereas the second section was based on the evaluation of risk management strategies of conventional and Islamic banks in Pakistan.

After the development of the questionnaire, it was tested through a pilot study of ten respondents. In this pilot study, the participants were asked to fill the questionnaire and report problems regarding the phrasing of questionnaires and their understandability. The participants were asked that whether questions are clear and understandable or not. This has allowed the researcher to correct specific problems in the questionnaire to avoid such issues in the main survey. After conducting pilot studies, sample for the study was chosen.

\section{Sample}

A sample of 150 respondents of conventional and Islamic banks of Pakistan has been chosen in this study. The sample was composed of relationship associates, chief risk officers, credit officers, senior risk managers, branch managers and financial controllers of Islam and traditional banks of Pakistan. The sample selection was made on the basis of convenience sampling technique. This particular sampling technique had been found useful in this study because it was easy to use. The selected banks were not easily accessible. In this regard, use of the complicated sampling technique could result in potential complications in this study. Therefore, the researcher relied on convenience and accessibility of respondents. Response rate achieved in this research was $81 \%$.

\section{Analysis tools and techniques}

The data collected through survey questionnaire was in the form of answers to questions. This data was quantified by tabulating it on the software. By using the progressive scale, the data was quantified and précised to analyse it statistically. The statistical analysis has helped the researcher to point out the differences in the risk management strategies of conventional and Islamic banks of Pakistan. In this regard, average score was calculated to evaluate the risk management strategies of Islamic and conventional banks in Pakistan. The results of research have been effective to proof that whether there exist differences in the risk management strategies of conventional and Islamic banks of Pakistan.

\section{Results and Analysis}

The results of this particular study have been analysed descriptively and statistically. This study revealed several facts regarding risk management strategies of conventional and Islamic banks of Pakistan. The study reflected that despite of several differences in the strategies, practices and concepts of risk management strategies of conventional and Islamic banks of Pakistan, the literature review has revealed that both types of bank also face similar types of risks with minor variations. The study has also reflected that because of less immunity, experience and newborn products and services, Islamic banks were more vulnerable to potential risks and losses. Therefore, it has been found that because of high vulnerability to risks, Islamic banks have developed more sophisticated risk management strategies and practices in comparison with traditional or conventional banks. The following table describes the responses of respondents regarding different types of risks in conventional and traditional banks of Pakistan.

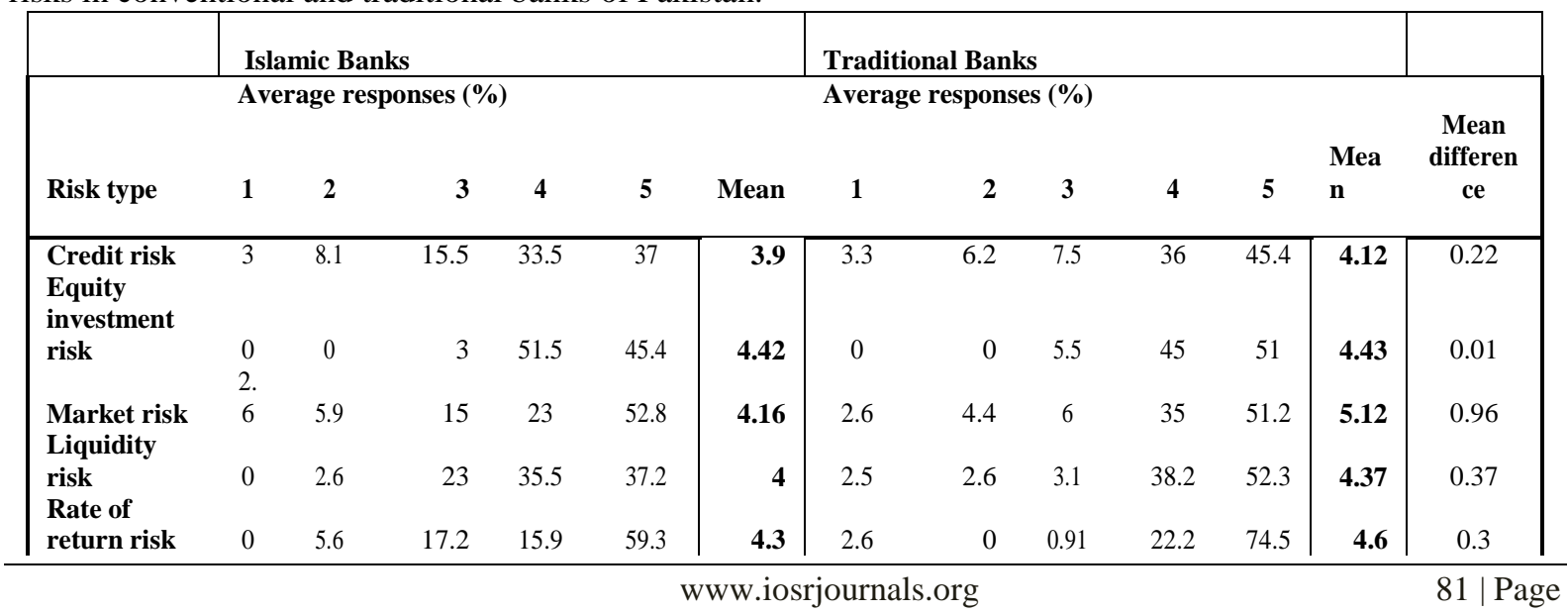




\begin{tabular}{|c|c|c|c|c|c|c|c|c|c|c|c|c|c|}
\hline $\begin{array}{l}\text { Operational } \\
\text { risk } \\
\text { Overall risk }\end{array}$ & $\begin{array}{l}2 . \\
3 \\
1 . \\
2\end{array}$ & 7.8 & 15.8 & 23.2 & 46.3 & 4.12 & 8.3 & 4.3 & 7.2 & 38.9 & $\begin{array}{c}33 \\
51.3\end{array}$ & $\begin{array}{l}3.78 \\
4.01\end{array}$ & 0.22 \\
\hline
\end{tabular}

The above table reveals that both types of banks face all types of risks. Therefore, both types of banks need to adopt risk management strategies. However, the above table also reveals that there exists a certain level of differences among different types of risks faced by Islamic and conventional banks in Pakistan. These minor differences can be attributed to sampling error of the study.

The results of this study have also reflected that there exist no significant differences between risk management practices of Islamic and conventional banks in Pakistan. However, the study also found that Islamic banks adopt some extra measures to manage risks faced by the banks. This is mainly because of the innovative nature of Islamic banks' products and services. In addition, Islamic banks do not have a substantial level of experience; hence they have to remain conscious of different types of risks. It has been concluded that credit risk, equity risk, investment risk, liquidity risk, operational risk and rate of return risks are faced equally by Islamic and conventional banks and there are no significant differences between risk management practices of both types of banks. These results are somewhat different from those of Tafri et al. (2011) which suggest that risk management practices of conventional and Islamic banks are different from each other. In this regard, it can be deduced that the Malaysian based study cannot be generalized and implemented in the banking industry of Pakistan because the Islamic banking industry is not highly developed in Pakistan rather it is on infancy stage.

\section{Conclusion}

On the basis of results of research, it has been concluded that risk management practices of Islamic and conventional banks in Pakistan are not significantly different from each other. Both types of banks face credit risk, equity risk, investment risk, liquidity risk, operational risk and rate of return risks in a similar manner. It has been concluded that Islamic banks are more conscious to adopt rigorous risk management practices and strategies as compared to conventional banks. The main reason behind this was because of innovativeness of Islamic banks which make these banks more vulnerable to new types of risks. However, this study also concluded that there exist no significant differences in the risk management practices of Islamic and conventional banks in Pakistan.

The results of this study cannot be generalized to a large population and overall banking industry of Pakistan because it was based on a small sample. Moreover, the questionnaire tool may include biased response of the research participants. A personally administered questionnaire may also have some limitations of biases in the responses. Therefore, future researchers are directed to use a more rigorous questionnaire for collection of data from respondents. In addition, they may also include large and diversified sample for generalizing results of this particular study.

\section{References}

[1]. Beck, T., Kunt, A., and Merrouche, O. (2013). Islamic vs. conventional banking: Business model, efficiency and stability, Journal of Banking and Finance, Vol. 37 (2) pp. 433 - 447

[2]. Hasan, M. and Dridi, J. (2010). The effects of the Global Crisis on Islamic and Conventional Banks: A comparative Study, IMF Working Paper No. 10 .

[3]. Nawi et al. (2013). A Critical Literature Review for Islamic Banks Selection Criteria in Malaysia,

[4]. Gitman, L.J. (2008), Principles of Managerial Finance, 11th ed., Dorling Kindersley (India) Pvt. Ltd., Licensees of Pearson Education in South Asia, Delhi.

[5]. Hassan, A. (2009), "Risk management practices of Islamic banks of Brunei Darussalam", The Journal of Risk Finance, Vol. 10 No. 1 , pp. 23-37

[6]. Tafri, F.H., Rahman, R.A. and Omar, N. (2011), "Empirical evidence on the risk management tools practised in Islamic and conventional banks", Qualitative Research in Financial Markets, Vol. 3 No. 2, pp. 86-104.

[7]. Abdullah, M., Shahimi, S. and Ismail, A.G. (2011), "Operational risk in Islamic banks: examination of issues", Qualitative Research

[8]. in Financial Markets, Vol. 3 No. 2, pp. 131-51.

[9]. Akkizidis, I.S. and Bouchereau, V. (2005), Guide to Optimal Operational Risk \& Basel II, Auerbach, Boca Raton, FL. 